\title{
Original article \\ Equal prefrontal cortex activation between males and females in a motor tasks and different visual imagery perspectives: A functional near- infrared spectroscopy (fNIRS) study
}

\author{
Thiago F. Dias Kanthack \\ Marcelo Bigliassi \\ Leandro Ricardo Altimari \\ State University of Londrina, Brazil
}

\begin{abstract}
The purpose of this study was to compare the prefrontal cortex (PFC) blood flow variation and time on in males and females while performing a motor task and imagery perspectives. Eighteen right handed subjects (11 males and 7 females) were volunteers to this study. All subjects went through three randomly conditions, a motor task condition (MT) in which they had to do a simple finger tap. The other conditions included practicing imagery in first and third views. During all the conditions, the fNIRS device was attached to the subject forehead to obtain the blood flow; the total time in each task which was measured with a chronometer. No difference had been found in any condition for both sexes in the PFC and time, nor for all subjects integrated in the PFC. Therefore, we conclude that both imageries can be used to mentally train a motor task, and probably both sexes can be benefited.
\end{abstract}

Keywords: imagery, prefrontal cortex, sex

Resumo- “Ativação do córtex pré-frontal durante tarefas motoras e perspectivas de diferentes imagens visuais em homens e mulheres: Um estudo com espectroscopia por reflectância infravermelho funcional (fNIRS)." O objetivo do estudo foi comparar a variação sanguínea do córtex prefrontal (CPF) e o tempo de realização, durante uma tarefa motora e diferentes perspectivas de imagética motora em homens e mulheres. Dezoito sujeitos destros (11 homens e 7 mulheres) foram voluntários. Todos os sujeitos passaram por 3 condições randomicamente, uma tarefa motora que consistia em uma simples batida de dedos. As outras condições fora a prática de imagética motora em primeira e terceira pessoa. Durante todas as condições, um aparelho fNIRS foi acoplado a testa para obtenção do fluxo sanguíneo; e o tempo total de cada tarefa foi obtido com um cronômetro. Nenhuma diferença foi encontrada em nenhuma condição para ambos os gêneros no CPF e no tempo, bem como quanto considerados todos os sujeitos. Concluímos que ambas imagéticas podem ser usadas para treinar mentalmente uma tarefa motora e que, provavelmente, ambos os gêneros podem se beneficiar da técnica.

Palavras-chaves: imagens, córtex pré-frontal, sexo

Resumen- - "La activación de la corteza prefrontal durante las tareas motrices y perspectivas de diferentes imágenes visuales en los hombres y las mujeres: Un estudio de la espectroscopia de reflectancia en el infrarrojo funcional (fNIRS)." El propósito de este estudio fue comparar la actividad de la corteza frontal (CF) y el tiempo del realización de una tarea motora en diferentes perspectivas del entrenamiento mental. Dieciocho participantes diestros (11 hombres y 7 mujeres) fueron voluntarios en este estudio. Todos los participantes realizaram tres condiciones aleatorias: tarea motora (TM), dónde hicieron golpes con los dedos en una secuencia determinada. Las otras condiciones estaban practicando el entrenamiento mental vistas en primera y tercera persona. Durante todas las condiciones, el dispositivo fNIRS estaba unido a la frente del sujeto para obtener el flujo de sangre; el tiempo total de cada tarea se midió con un cronómetro. Ninguna diferencia se había encontrado en ninguna condición para ambos sexos y el tiempo. Por lo tanto, llegamos a la conclusión de que ambas las formas de imaginación pueden utilizar para entrenar mentalmente una tarea motora, y probablemente ambos géneros pueden ser beneficiados.

Palabras claves: imágenes, corteza frontal, sexo.

\section{Introduction}

Motor imagery is defined as a mental dynamic action without any corresponding overt body movement. There several evidences that motor imagery contribute to improve motor recovery (Dettmers, Benz, Liepert, \& Rockstroh, 2012; Guttman, Burstin, Brown, Bril, \& Dickstein, 2012), motor learning (Nyberg, Ericksson, Larsson, \& Marklund, 2006) and sport performance, from beginners to professional 
(Lejeune, Deckers, \& Sanches, 1994; Seif-Barghi, Kordi, Memari, Mansournia, \& Jalali-Ghomi, 2012; Guillot, Genevois, Desliens, Saieb, \& Rogowski, 2012; Moran, Guillot, Macintyre, \& Collet, 2012). Imagery effectiveness might be explained by the degree of functional equivalence between physical practice and mental simulation of the same movement; these two forms of practice are mediated by overlapping neural networks (Munzert, Lorey, \& Zentgraf, 2009; Guillot, Di Rienzo, Macintyre, Moran, \& Collet, 2012).

Among the motor-related structures activated by both, actual and imagined movements, the prefrontal cortex (PFC) is known to play a critical role (Leff, Orihuela-Espina, Elwell, Athanasiou, Delpy, Darzi, \& Yang, 2011). Changes in the PFC blood flow indicate the need for sending motor outputs, meaning that in a motor task the blood flow from the PFC will suffer changes (Obrig, Hirth, Junge-Hulsing, Doge, Wolf, Dirnagl, \& Villringer, 1996). Based on the effectiveness of motor imagery affecting the motor learning process (for a review, see Schuster, Hilfiker, Amft, Scheidhauer, Andrews, Butler, Kischka, \& Ettlin, 2011), it is assumed that similar blood flow variations might be recorded in the PFC during motor imagery simultaneous to the execution of the same action.

More recently, some studies have suggested the use of functional near-infrared spectroscopy (fNIRS) (Holper, Kobashi, Kiper, Scholjmann, Wolf, \& Eng, 2012; Holper, \& Wolf, 2011) to obtain a greater knowledge regarding the imagery use, and also suggested the need for comparing its use in in both sexes (Ishizu, Noguchi, Ito, Ayabe, \& Kojima, 2009).

Yet, several experimental studies investigated the efficacy of motor imagery regardless the sex of the participants. While some of them included only males or females, others included both within the same experimental groups (e.g., Lohr \& Scogin, 1998; Bar-Eli \& Blumenstein, 2004; Guillot, Genevois, Desliens, Saieb, \& Rogowski, 2012). In their research, LeonCarrion, Damas, Izzetoglu, Pourrezai, Martín-Rodríguez, Barroso, Martin, and Dominguez-Morales (2006) provided evidence of different PFC activations, using a functional near-infrared spectroscopy (fNIRS) device, while males and females watched a video or observed pictures. However, it remains unknown whether or not similar changes are observed during motor imagery, thus, demonstrating that males and females have a different brain activation from external stimulus (videos and pictures), leaving the question about internal stimulus unanswered (e.g. motor imagery).

Another interesting question is the difference between internal visual imagery (first-person perspective) and external visual imagery (third-person perspective). Imagery research generally demonstrated that all imagery perspectives can serve different purposes, and that their effectiveness may depend on the nature of the task being imagined (Hardy, \& Callow, 1999; Carlow, \& Hardy, 2004). More recently, Callow and Roberts (2010) underlined the importance of the individual imagery perspective preference; Di Rienzo, Collet, Hoyek, and Guillot (2012) further demonstrated that internal imagery was more affected by physical fatigue, probably due to its close relationship with actual practice. The observed effect of physical fatigue when performing internal imagery might account for central processes affecting the internal representation of the motor sequence. Based on these findings, we assume that PFC activations may be selectively affected by the imagery perspective.

The main purpose of our study was, therefore, to investigate blood flow variations in the PFC during internal and external imagery of the same movement. The effect of sex was also considered.

\section{Method}

\section{Participants}

Eighteen healthy volunteers (11 males and 7 females; $22.25 \pm 2.34$ years) participated in the present study. All were right-handed and the experimental procedure was explained before the tests. All participants signed an informed consent form and the study was performed according to Helsinki Declaration and approved by the local ethics committee. Adults were recruited from the Physical Education and Sports Center of the State University of Londrina. None had any physical or intellectual problem, and all were refrained from caffeine, alcohol and nicotine at least three hours before the experiment.

\section{Experimental design}

All participants underwent a neuroimaging test during actual practice and motor imagery of a simple motor task. An fNIRS device (Biopac Systems ${ }^{\circledR}$ - 16 voxels; 10 photo detectors; 4 photo emitters; $2.5 \mathrm{~mm}$ inter optode distance) was used to assess blood flow variations during each condition (Figure 1). The fNIRS sensors were located in line with positions in agreement with the International 10-20 System, designed for recording data from the dorsolateral prefrontal cortex (dlPFC), the device being positioned on the forehead $0.5 \mathrm{~cm}$ above the eyebrow. All experimental procedures were performed in a dark room avoiding external light interferences. A luminous signal penetrating biological tissue such as the skull and brain consecutively allowed quantification, via reflex of chromospheres within molecules of hemoglobin, of the cerebral oxygenation divided by both sides of dlPFC. The instrument was developed according to Chance and Leigh that is based on the modified Beer-Lambert Law. Each light source contained two light-emitting diodes with wavelengths of 730 and $850 \mathrm{~nm}$, representing the reflection of deoxyhaemoglobin $(\mathrm{HHb})$ and oxyhaemoglobin $(\mathrm{O} 2 \mathrm{Hb})$, respectively.

Initially, participants remained seated (Figure 2) until their $\mathrm{O} 2 \mathrm{Hb}$ and $\mathrm{HHb}$ values showed a linear scattering. Thereafter, baseline values were calculated during ten seconds, with white noise as background sound (see Figure 3 for a visual example of the signal in the computer).

Participants then performed a simple finger tapping task starting with one tap with forefinger, 2 taps from the middle 


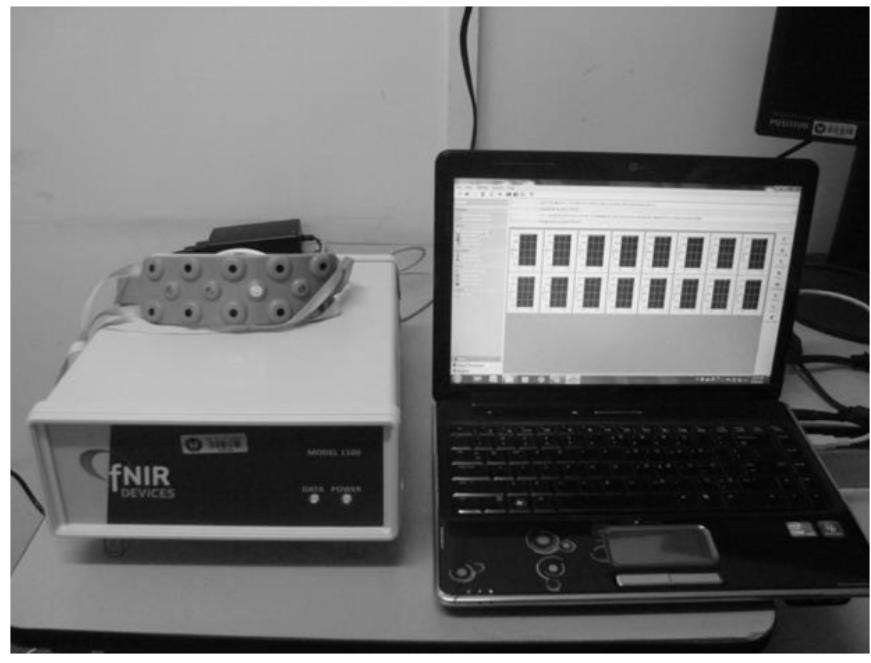

Figure 1. fNIRS device used (Biopac Systems ${ }^{\circledR}$ - 16 voxels; 10 photo detectors; 4 photo emitters; $2.5 \mathrm{~mm}$ inter optode distance).

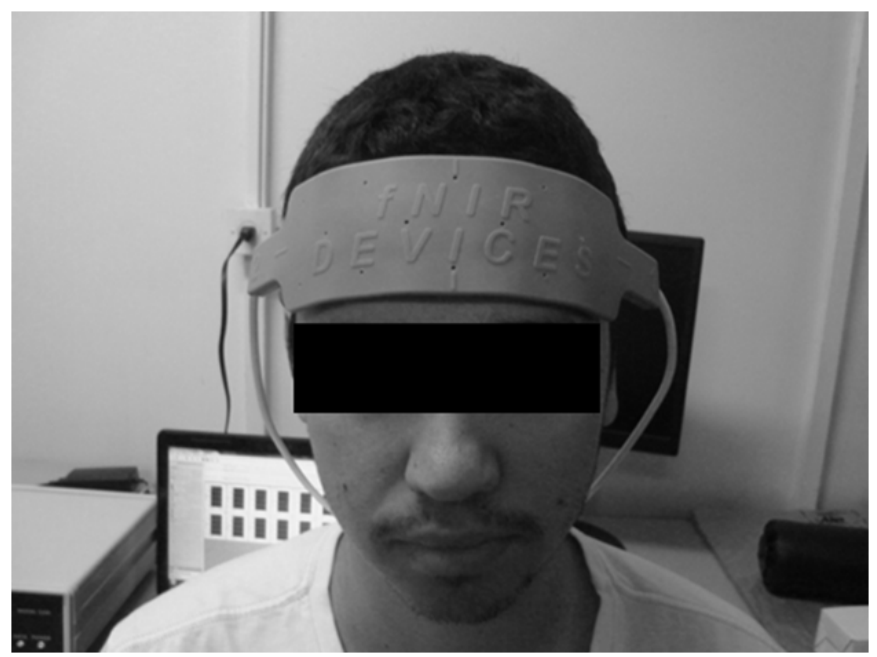

Figure 2. Participant seated using fNIR device to obtain blood flow during motor imagery. finger, 3 taps with the ring finger and 4 taps with the pinkie finger (Figure 4). This sequence was performed four times. Then, after five minutes, participants were requested to mentally rehearse the same motor sequence, either in a firstperson or third-person perspective, this task was chosen due the instrument limitations for more intensive activities and for been a medium-complex task capable of achieve the research purpose (Holper \& Wolf, 2011). The order of imagery conditions was randomized using a coin. $\mathrm{O} 2 \mathrm{Hb}$ and $\mathrm{HHb}$ values were added to represent the blood flow variation of baseline. Also, the total time of each task was assessed with a digital chronometer. In the imagery conditions, participants were asked to provide two signals informing the beginning and the end of task. Finally, we checked before the experiment that all participants were able distinctly performing first-person and third-person imagery perspectives.

\section{Data processing}

A moving average window of 0.5 seconds was applied to each dependent variable of fNIRS. Voxels 1 to 8 were grouped in order to compose the left side of PFC, the voxels 9 to 16 were grouped in order to compose the right side of PFC. fNIRS data were analyzed using a software developed on excel 2010 (Microsoft Office ${ }^{\circledR}$ ) to stratify, count, share by voxels and $\mathrm{PFC}$ side, generating $\mathrm{O} 2 \mathrm{Hb}$ and $\mathrm{HHb}$ values, that were added together performing the variation of blood flow to each side of PFC.

\section{Data analysis}

Statistical analyses were performed using SPSS 17.0 (SPSS Inc ${ }^{\circledR}$, Chicago, IL, USA). The normality of the data was tested using Shapiro-Wilk's test. The data was found not Gaussian, with their scattering ranging from negative to positive values and unabling a logarithmic transformation. Therefore, an order squares sum was calculated to rank the

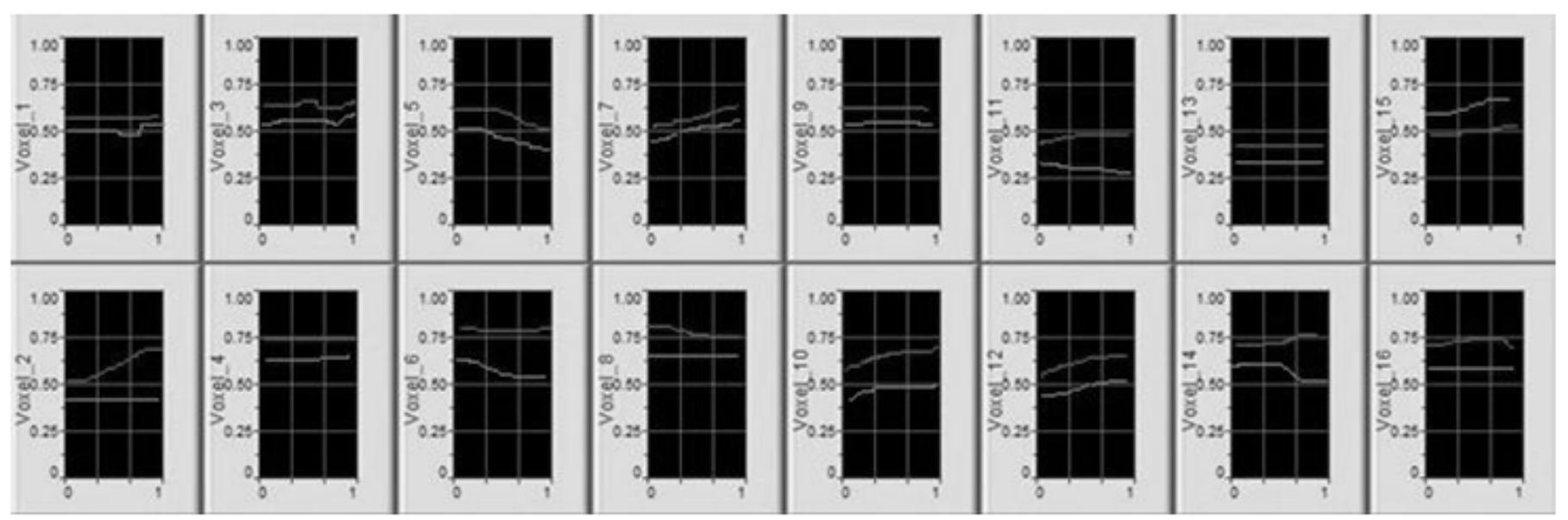

Figure 3 - fNIRS interface. Lines demonstrate the blood flow variation for each voxel. 


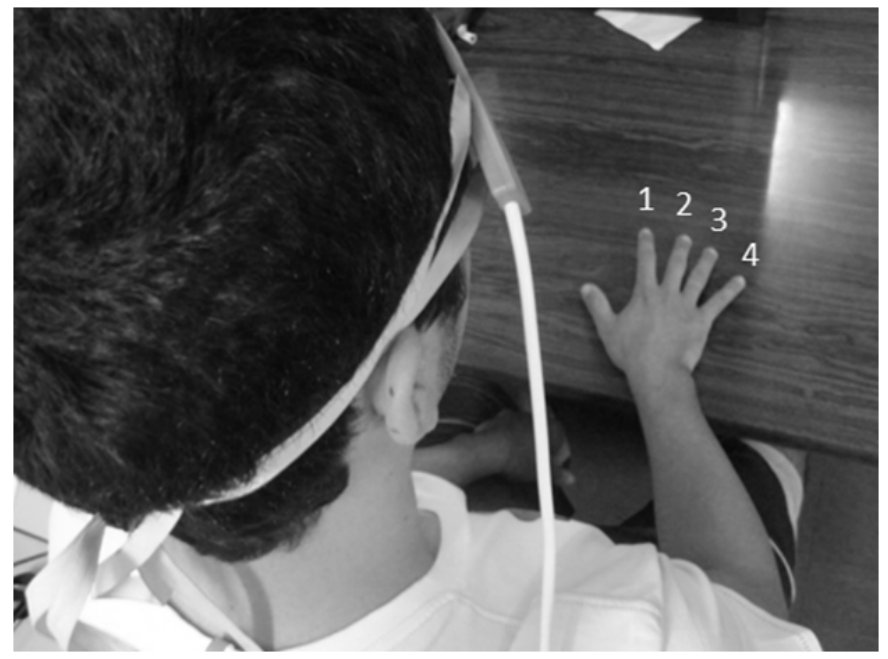

Figure 4. Participant performing finger tap during a proposed motor task.

observations. The smallest value option at assign rank area was used to calculate the tie rank, and then it was used in a nonparametric ANOVA two-way (conditions $\mathrm{x}$ sex $=3 \times 2$ ) as suggested by Marôco (2011). Each side of brain was compared separately. Parametric ANOVA one-way was used to compare transformed total time $(\log 10)$ for each condition between sexes.

\section{Results}

Table 1 presents dlPFC blood flow variations and time of each task during all experimental conditions. No differences were found neither for sex nor for condition comparisons.
Also, statistical analysis did not reveal any difference when comparing movement times $(\mathrm{MM}=20.5 \pm 5.1 \mathrm{~s} ; \mathrm{WM}=20.4 \pm$ $3.3 \mathrm{~s} ; 1 \mathrm{M}=31.7 \pm 12.6 \mathrm{~s} ; 1 \mathrm{~W}=24.5 \pm 6.5 \mathrm{~s} ; 3 \mathrm{M}=28.1 \pm 7.4 \mathrm{~s}$; $3 \mathrm{~W}=25 \pm 6.1 \mathrm{~s} ; \mathrm{F}=0.136 ; p=0.874)$.

\section{Discussion}

Our study aimed at comparing dlPFC blood flow variations in males and females during first- and third-person motor imagery. We used the fNIRS device, a well validated instrument to accomplish it (Khoa \& Nakagawa, 2008). Data did not reveal any sex nor imagery perspective effect, i.e. similar dlPFC blood flow variations were recorded in all experimental conditions.

We expected first-person imagery as being closer to the actual motor task than the third-person imagery perspective. About the time to accomplish the task and motor imagery (in both conditions), the finding was exactly what was expected, following the findings of Di Rienzo, Collet, Hoyek, and Guillot (2012) in the pretest situation. Data, however, revealed that PFC blood flow variations were similar during the two types of imagery, which were also both comparable to those recorded during actual practice. This lack of difference may had occurred due to the non familiarization of the subjects to the motor imagery technique or even to the motor task, which is recommended that the subject have a previous knowledge (Olson \& Nyberg, 2010). Also, our results conflicts with the findings of Ishizu, Noguchi, Ito, Ayabe, and Kojima (2009), where sex difference was found, nevertheless, in their study a visual stimulus was also used to compared to physical and imagery practice; assuming females and males have different brain responses to external stimulus (Leon-Carrion, Damas, Izzetoglu, Pourrezai, MartínRodríguez, Barroso, Martin, \& Dominguez-Morales, 2006) that may alter the imagery process, the authors concluded

Table 1. dlPFC blood flow variations. Data are presented in median and interquartile ranges for right and left variables, and in mean and standard deviation for total time $(\log 10)$.

\begin{tabular}{|c|c|c|c|c|}
\hline \multirow[t]{3}{*}{ Men } & & Imagery 1 & Imagery 3 & Motor task \\
\hline & Right $\mu \mathrm{M}$ & $-0.75(8.15)$ & $0.81(5.57)$ & $0.11(4.52)$ \\
\hline & Left $\mu \mathrm{M}$ & $0.59(2.84)$ & $0.92(5.51)$ & $-0.35(7.06)$ \\
\hline Total time (s) & & $1.46 \pm 0.14$ & $1.42 \pm 0.14$ & $1.25 \pm 0.27$ \\
\hline \multicolumn{5}{|l|}{ Women } \\
\hline & Right $\mu \mathrm{M}$ & $0.19(0.20)$ & $0.03(0.27)$ & $-0.22(0.45)$ \\
\hline & Left $\mu \mathrm{M}$ & $0.17(0.28)$ & $0.17(0.38)$ & $-0.14(0.85)$ \\
\hline Total time (s) & & $1.32 \pm 0.15$ & $1.31 \pm 0.13$ & $1.28 \pm 015$ \\
\hline
\end{tabular}


that more studies would be necessary to completely answer this phenomenon.

Perhaps the number of subjects in this study was not enough to find differences in the outcomes, especially because of the different number of males and females in the sample. This limitation should be taken in consideration for future studies. The fNIRS device limits the research to controlled tasks in a laboratory environment (e.g., Zimmermann, Marchal-Crespo, Edelmann, Lambercy, Fluet, Riener, Wolf, \& Gasset, 2013; Xu, Hong, \& Ge, 2013). Since motor imagery has many different applications (Schuster, Hilfiker, Amft, Scheidhauer, Andrews, Butler, Kischka, \& Ettlin, 2011) it would be of great advantage to use devices that allow more ecological contexts, especially in sports where the performance is quite different between males and females. Yet, we would like to highlight that those results were found only in the dlPFC, while other studies showed different brain activation when compared imagery in first and third view (Vingerhoets, Stevens, Meesdom, Honoré, Vandemaele, \& Achten, 2012; Fourkas, Bonavolontà, Avenanti, \& Saglioti, 2006).

To summarize, the present results provide evidence that first and third-person imagery perspectives yield a similar blood flow variation on PFC compared to the execution of a fine motor coordinator task. We did not find any sex effect when comparing all experimental conditions as well. Finally, similar findings were found when looking at the time required to perform/imagine the task. Thus, we recommend that future studies compare motor imagery use in males and females to check if those results are ecologically valid. And also, first and third person views seem to provide a similar dlPFC activation, therefore, both can be equally used.

\section{References}

Bar-Eli, M., \& Blumentein, B. (2004). Performance enhancement in swimming: the effect of mental training with biofeedback. Journal of Science and Medicine in Sport, 7(4), 454-464. Retrieved from http://www.sciencedirect.com/science/article/ pii/S1440244004802640

Callow, N., \& Hardy, L. (2004). The relationship between the use of kinaesthetic imagery and different visual imagery perspectives. Journal of Sports Sciences, 22, 167-177. Retrieved from http://www.castonline.ilstu.edu/smith/405/readings_pdf/ callow\%20hardy\%20imagery.pdf

Callow, N., \& Roberts, R. (2010). Imagery research: An investigation of three issues. Psychology of Sport and Exercise, 11(4), 325-329. http://dx.doi.org/10.1016/j.psychsport. 2010.03.002

Dettmers, C., Benz, M., Liepert, J., \& Rockstroh, B. (2012) Motor imagery in stroke patients, or plegic patients with spinal cord or peripheral diseases. Acta Neurologica Scandinavica, 126(2), 238-247. doi: 10.1111/j.1600-0404.2012.01680

Di Rienzo, F., Collet, C., Hoyek, N., \& Guillot, A. (2012). Selective effect of physical fatigue on motor imagery accuracy. PLoS One, 7(10). Retrieved from http://www.plosone.org/article/ info:doi/10.1371/journal.pone.0047207

Fourkas, A., Bonavolontà, V., Avenanti, A., \& Saglioti, S. M. (2008). Kinesthetic imagery and tool-specific modulation of corticospinal representations in expert tennis players. Cerebral Cortex, 18(10), 2382-2390. doi: 10.1093/cercor/bhn005

Guillot, A., Di Rienzo, F., Macintyre, T., \& Collet, C. (2012). Imagining is Not Doing but Involves Specific Motor Commands: A Review of Experimental Data Related to Motor Inhibition. Frontiers in Human Neuroscience, 6(247). doi: 10.3389/fnhum.2012.00247

Guillot, A., Genevois, C., Desliens, S., Saieb, S., \& Rogowski, I. (2012). Motor imagery and 'placebo-racket effects' in tennis serve performance. Psychology of Sport and Exercise, 13, 533540. Retrieved from http://www.sciencedirect.com/science/ article/pii/S1469029212000325

Guttman, A., Burstin, A., Brown, R., Bril, S., \& Dickstein, R. (2012). Motor imagery practice for improving sit to stand and reaching to grasp in individuals with poststroke hemiparesis. Topics of Stroke Rehabilitation, 19(4), 306-319. doi: 10.1310/ tsr1904-306.

Hardy, L., \& Callow, N. (1999). Efficacy of external and internal visual imagery perspectives for the enhancement of performance on tasks in which form is important. Journal of Sport and Exercise Psychology, 21(2), 95-112. Retrieved from http://www.getcited.org/pub/103340303

Holper, L., \& Wolf, M. (2011). Single-trial classification of motor imagery differing in task complexity: a functional near-infrared spectroscopy study. Journal of Neuroengineering Rehabilitation, 8(34). doi: 10.1186/1743-0003-8-34.

Holper, L., Kobashi, N., Kiper, D., Scholkmann, F., Wolf, M., \& Eng, K. (2012). Trial-to-trial variability differentiates motor imagery during observation between low versus high responders: a functional near-infrared spectroscopy study. Behavioural Brain Research, 229(1), 29-40. doi: 10.1016/ j.bbr.2011.12.038.

Hu, X. S., Hong, K. S., \& Ge, S. S. (2013). Reduction of trial-totrial variability in functional near-infrared spectroscopy signals by accounting for resting-state functional connectivity. Journal of Biomedical Optics, 18(1), 17003. doi: 10.1117/1.JBO.18.1. 017003.

Khoa, T. Q., \& Nakagawa, M. (2008). Recognizing brain activities by functional near-infrared spectroscope signal analysis. Nonlinear Biomedical Physics, 2(3). doi: 10.1186/1753-46312-3.

Ishizu, T., Noguchi, A., Ito, Y., Ayabe, T., \& Kojima, S. (2009) Motor activity and imagery modulate the body-selective region in the occipital-temporal area: a near-infrared spectroscopy study. Neuroscience Letters, 465(1), 85-89. doi: 10.1016/ j.neulet.2009.08.079.

Leff, D. R., Orihuela-Espina, F., Elwell, C. E., Athanasiou, T., Delpy, D. T., Darzi, A.W., \& Yang G. Z. (2011). Assessment of the cerebral cortex during motor task behaviours in adults: a systematic review of functional near infrared spectroscopy (fNIRS) studies. Neuroimage, 54(4), 2922-2936. doi: 10.1016/ j.neuroimage.2010.10.058.

Lejeune, M., Deckers, C., \& Sanches, X. (1994). Mental rehearsal in table tennis performance. Perceptual and Motor Skills, 79(1pt2), 627-641. Retrieved from http://pubget.com/paper/ 7808903/Mental_rehearsal_in_table_tennis_performance

Leon-Carrion, J., Damas, J., Izzetoglu, K., Pourrezai, K., MartínRodríguez, J. F., Barroso., ... Dominguez-Morales, M. R. (2006). Differential time course and intensity of PFC activation for men and women in response to emotional stimuli: a functional near-infrared spectroscopy (fNIRS) study. Neuroscience letters, 403(1-2), 90-95. Retrieved from http:// www.sciencedirect.com/science/article/pi / S0304394006004125 
Lohr, B. A., \& Scogin, F. (1998). Effects of self-administered visuomotor behavioral rehearsal on sport performance of collegiate athletes. Journal of Sport Behavior, 21(2), 206-218. Retrieved from http://www.cabdirect.org/abstracts/19981809089.html; jsessionid=331870ED5608A05CF622659A3B2B 7CE9 ?gitCommit=4.13.29

Marôco, J. (2011). Análise Estatística com o SPSS Statistics (5 ${ }^{\mathrm{a}}$ ed). Lisbon: ReportNumber. Avaible on http://geografiametodos-planeamento.blogspot.com.br/2011/09/joao-maroco2011-analise-estatistica.html

Moran, A., Guillot, A., Macintyre, T., \& Collet, C. (2012). Reimagining motor imagery: building bridges between cognitive neuroscience and sport psychology. British Journal of Psychology, 103(2), 224-47. doi: 10.1111/j.2044-8295.2011. 02068.x.

Munzert, J., Lorey, B., \& Zentgraf, K. (2009). Cognitive motor processes: the role of motor imagery in the study of motor representations. Brain Research Review, 60(2), 306-326. doi: 10.1016/j.brainresrev.2008.12.024.

Nyberg, L., Erickson, J., Larsson, A., \& Marklund, P. (2006). Learning by doing versus learning by thinking: An fMRI study of motor and mental training. Neuropsychologia, 44(5), 711717. Retrieved from http://www.sciencedirect.com/science/ article/pii/S0028393205002721

Obrig, H., Hirth, C., Junge-Hulsing, J. G., Doge, C., Wolf, T., Dirnagl, U., \& Villringer, A. (1996) Cerebral oxygenation changes in response to motor stimulation. Journal of applied physiology, 81(3), 1174-1183. Retrieved from http:// jap.physiology.org/content/81/3/1174.long

Olsson, C. J., \& Nyberg, L. (2010). Motor imagery: if you can't do it, you won't think it. Scandinavian Journal of Medicine in Science \& Sports, 20(5), 711-715. doi: 10.1111/j.16000838.2010.01101.x..

Schuster, C., Hilfiker, R., Amft, O., Scheidhauer, A., Andrews, B., ... Ettlin, T. (2011). Best practice for motor imagery: a systematic literature review on motor imagery training elements in five different disciplines. BMC Medicine. 9(75). doi: 10.1186/ 1741-7015-9-75.

Seif-Barghi, T., Kordi, R., Memari, A. H., Mansournia, M. A., \& Jalali-Ghomi, M. (2012). The effect of an ecological imagery program on soccer performance of elite players. Asian Journal of Sports Medicine, 3(2), 81-89. Retrieved from http:// www.ncbi.nlm.nih.gov/pmc/articles/PMC3426726/

Vingerhoets, G., Stevens, L., Meesdom, M., Honoré, P., Vandemaele, P., \& Achten, E. (2012). Influence of perspective on the neural correlates of motor resonance during natural action observation. Neuropsychological Rehabilitation, 22(5), 752 767. doi: 10.1080/09602011.2012.686885.

Zimmermann, R., Marchal-Crespo, R., Edelmann, J., Lambercy, O., Fluet, M. C., Riener, R., ... Gassert, R. (2013). Detection of motor execution using a hybrid fNIRS-biosignal BCI: a feasibility study. Journal of Neuroengineering and Rehabilitation, 21(10). doi:10.1186/1743-0003-10-4

\section{Authors' note}

Thiago F. Dias Kanthack is a master's student in the graduate program in physical education in a conjoined program of the State University of Londrina and State University of Maringá

Marcelo Bigliassi and Leandro Ricardo Altimari are affiliated with the State University of Londrina, Center of Physical Education and Sport, Londrina, Paraná, Brazil. Group of Study and Research in Neuromuscular System and Exercise (GEPESINE)

\section{Correspondence}

Thiago F. Dias Kanthack

E-mail: thiago_fdk@hotmail.com

\section{Acknowledgments}

The authors would like to thank CNPq and CAPES for graduate scholarships. We would like to thank Dr. Aymeric Guillot of Centre de Recherche et d'Innovation sur le Sport de Université de Lyon, France, for his kind contribution to this paper.

This study was presented at the $8^{\text {th }}$ International Congress of Physical Education and Human Movement and $14^{\text {th }}$ Symposium Paulista Physical Education.

Declaration of Conflicting Interests: The authors declared no conflicts of interest exist with respect to the research, authorship, and/or publication of this article.

Manuscript received on February 13, 2013

Manuscript accepted on April 18, 2013 